UDC 378.2.011.3-051:316.61

DOI https://doi.org/10.31470/2415-3729-2020-12-163-183

\title{
Training Future Teachers for Preschoolers' Socialization in the Interaction of Preschool Educational Establishments and Family
}

\section{Tetiana Rozhko-Pavlyshyn}

Doctor of Philosophy in Pedagogy (Ph.D), Associate Professor, Department of Pedagogy and Methodology of Primary and Preschool Education,

Ternopil Volodymyr Hnatiuk National Pedagogical University

$\triangle$ 2, M. Kryvonosa Str., Ternopil, Ukraine, 46027

E-mail: tana.rzhk@gmail.com

ORCID: http://orcid.org/0000-0003-2781-5982

Date of receipt of the article: September 28, 2020 Article accepted for publication: November 22, 2020

\section{Підготовка майбутніх вихователів до соціалізації дошкільників у взасмодії ЗДО і сім’ї}

\section{Рожко-Павлишин Тетяна Андріївна}

к.п.н., доцент кафедри педагогіки і методики, початкової та дошкільної освіти , Тернопільського національного педагогічного університету ім. Володимира Гнатюка

$\triangle$ вул. Максима Кривоноса, 2, м. Тернопіль, Україна, 46027

Дата надходження статті: 28 вересня 2020 р. Стаття прийнята до друку: 22 листопада 2020 р. 


\section{Abstract}

The article focuses on the current issues of training future educators of preschool institutions for the preschool children's socialization in the context of interaction between preschool institution and family.

The research goal is to highlight the essence of the training future educators for the preschoolers' socialization in the interaction between preschool institutions and families in order to outline the content, key areas, forms and methods of this work.

Methods. The research methods used were observation, abstraction, analysis, synthesis, induction, deduction, systematization, generalization and modeling.

The results. The conducted research allowed the author to reveal the probable reasons for scientists' different interpretations of the concept of «socialization of the preschooler»; differentiate and logically organize the concepts related to the above, in the context of the interaction of preschool education institution and the family on the socialization of preschoolers; the purpose of professional pedagogical education is to train a competent specialist of innovative type, able to implement educational standards, apply new educational technologies, the use of appropriate tools, methods and forms of its implementation.

Conclusions. Today the purpose of professional pedagogical education is to train a competent specialist of innovative type, able to implement educational standards, apply new educational technologies. The article reveals the essence of the concepts «socialization of a preschooler», «preschooler's social competence» and «interaction of preschool education institution and family». It is noted that socialization is the gradual entry of the child into the system of social relations, mastering the socio-cultural experience. The author reveals the social significance of this problem, the system of organization of preschoolers' socialization, its features in children of this age, directions, forms and methods of work. The role of the family and preschool education institution as the most important social 
institutions that determine the specifics of social education, the formation of a minor, the problems and opportunities for socialization of children in the family and educational institution is shown. The article offers pedagogical conditions for optimizing the professional training of students to organize the socialization of preschoolers.

Key words: socialization of a preschooler, interaction of preschool education institution and family, preparation of future educators of preschool education institution to establish interaction of preschool education institution and family.

\section{References}

1. Boghush, A.M. \& Ghavrysh, N.V. (2006). Dity i socium: osoblyvosti socializaciji ditej doshkiljnogho ta molodshogho shkiljnogho viku [Children and society: features of socialization of children of preschool and primary school age]. Lughansjk : Aljma-mater [in Ukrainian].

2. Kravchenko, T. (2010). Teoretyko-metodychni zasady socializaciji ditej shkiljnogho viku [Theoretical and methodological and fundamentals of children's socialization of school age in the interaction of family and schools]. Extended abstract of candidate's thesis. Kyiv: The Institute of Problems on Education of the National Academy of Educational Sciences of Ukraine [in Ukrainian].

3. Levycjka, Gh.M. (2011). Adaptacija ditej rannjogho viku do dytjachogho sadka [Adaptation of young children to kindergarten]. Bibliotechka vykhovatelja dytjachogho sadkaKindergarten teacher's library, 3, 76-91 [in Ukrainian].

4. Lytvynenko, S.Ja. (2002). Dytyna i seredovyshhe: problemy vzajemodiji [Child and environment: problems of interaction] Onovlennja zmistu ta metodiv navchannja $i$ vykhovannja $v$ zakladakh osvity - Update the content and methods of teaching and education in educational institutions, 22, 216-219 [in Ukrainian].

5. Matishak M. V. (2015). Naprjamy spivpraci pedaghogha z batjkamy u procesi formuvannja socialjnoji kompetentnosti molodshykh shkoljariv [Directions of cooperation of the teacher 
with parents in the process of formation of social competence of junior schoolchildren]. Molodyj vchenyj - A young scientist, 2 (17), 279-282 [in Ukrainian].

6. Nacionaljna strateghija rozvytku osvity v Ukrajini na 20122021 rr. [National strategy for the development of education in Ukraine for 2012-2021] Retrieved from http://oneu.edu.ua/wpcontent/uploads/2017/11/nsro_1221.pdf [in Ukrainian].

7. Perkhajlo, N.A. (2018). Partnerstvo sub'jektiv socialjnoji roboty [Partnership of social workers]. PerejaslavKhmeljnycjkyj : «Kalyna» [in Ukrainian].

8. Roghaljsjka, I.P. (2008). Socializacija osobystosti u doshkiljnomu dytynstvi: sutnistj, specyfika, suprovid [Socialization of personality in preschool childhood: essence, specificity, support]. Kyjiv : Milenium, [in Ukrainian].

9. Sajko, N.O. (2004). Profesijno-pedaghoghichna pidghotovka majbutnikh vykhovateliv do socializaciji ditej doshkiljnogho viku [Professional and pedagogical training of future educators for the socialization of preschool children]. Candidate's thesis. Kyiv: The Institute of Problems on Education of the National Academy of Educational Sciences of Ukraine [in Ukrainian].

10. Shakhraj, V. (n.d.) Kryteriji ta pokaznyky vyznachennja sformovanosti socialjnoji kompetentnosti osobystosti [Criteria and indicators for determining the formation of social competence of the individual]. Retrieved from http://narodnaosvita.kiev.ua/ Narodna_osvita/vupysku/15/statti/shahray.htm [in Ukrainian].

\section{Вступ}

Становлення громадянського суспільства, що об'єднує свідомих, активних і креативних особистостей, здатних до рішучих дій, вимагає формування таких індивідів якнайраніше, із молодшого віку. Це завдання постає не лише перед закладами дошкільної освіти, покликаних всебічно розвивати дітей, готувати їх до подальшого навчання, але й перед сім'єю як найголовнішим виховним середовищем, що підсилює (чи знижує) ефективність освітнього процесу. 
Традиційно вивчення ролі й можливостей закладів освіти та родини в соціальному вихованні дитини відбувається паралельно. Пріоритетні цілі системи освіти сьогодні скеровують на послідовну адаптацію дошкільника до соціального оточення, формування міцних підвалин розвитку особистості як активного члена суспільства. Водночас сім'я залишається найвагомішим інститутом соціалізації, покликаним відкрити перед дитиною цілий світ у всій його різноманітності, закономірностях, зокрема й підготувати до життя в громаді, формувати світогляд неповнолітніх тощо. Значущість кожного 3 названих напрямів виховання особистості важко переоцінити. Кожен із них потребує детального розгляду й подальшого розвитку. Однак тільки гармонізація та координація зусиль закладу освіти й сім’ї забезпечить належне входження дитини в соціум, соціалізацію дошкільника загалом.

Саме на партнерство сім’ї і навчального закладу зорієнтовані чинні нормативно-правові освітні документи (закони України «Про освіту», «Про дошкільну освіту» «Про охорону дитинства», Концепція «Нова українська школа»; Національна стратегія розвитку освіти в Україні на період до 2021 року; Концепція розвитку освіти України на період 2015-2025 років, міжнародні документи - Конвенція ООН про права дитини, Європейська конвенція про здійснення прав дітей, «Гаазька Конвенція про юрисдикцію), що обгрунтовують концептуальні засади єдності названих виховних впливів, їх взаємодоповнення і взаємозбагачення. Наприклад Національна стратегія розвитку освіти в Україні на 2012-2021 рр. окреслює стратегічні лінії сталого розвитку освіти, серед яких: «побудова ефективної системи національного виховання на засадах загальнолюдських, полікультурних, громадянських цінностей, забезпечення фізичного, морально-духовного, культурного розвитку дитини, формування соціально зрілої творчої особистості, громадянина України і світу, підготовка молоді до свідомого вибору сфери життєдіяльності», а також «забезпечення 
домінуючої відповідальності інституту родини за освіту і виховання дітей (Національна стратегія розвитку освіти в Україні на 2012-2021 рр.)».

Небувалої гостроти сьогодні набуває питання соціалізації дошкільників у контексті налагодження взаємодії закладу дошкільної освіти та сім’ї з метою соціального виховання особистості, іiі мотивації на самореалізацію в соціумі, теоретичне осмислення і методичне вирішення означеної проблеми.

Аналізування останніх публікащій. Оновлення завдань та змісту професійної підготовки майбутніх вихователів передбачає формування генерації нових компетентних професіоналів дошкільної освіти, здатних до педагогічного супроводу соціалізації дітей в умовах взаємодії ЗДО і сім’ї.

Насамперед необхідно встановити основні напрями наукового пошуку з проблеми організації співпраці закладу дошкільної освіти і сім’ї, різних аспектів її розгляду, серед яких: «педагогіка взаємодії» (Т. Алексєєнко, А. Бєлкін, А. Богуш, Л. Врочинська, Л. Загик, І. Зимова, С. Коротаєва, А. Кравченко, Н. Кирста, Г. Лактіонова, Н. Лисенко, Т. Маркова, Л. Островська, Т. Поніманська, В.Постовий та ін.); «педагогіка підтримки» (О. Газман, Н. Михайлова, С. Юсфін і т.д.); «педагогіка співробітницької взаємодії» (А. Адлер, Л. Байбородова, Г. Бєлєнька, Т. Гордон, Р. Дрейкурс, О. Кононко, О. Косарєва, М. Крухлет, М. Машовець, Я. Хямяляйнен та ін.). Важливими $є$ спеціальні дисертаційні дослідження з названої проблеми (О. Глузман, О. Друганова, С. Золотухіна, М. Свтух, В. Курило, О. Микитюк, С. Микитюк, В. Майбородова, Н. Побірченко, Н. Пузиркова, О. Рацул і т.д.).

Засадничими вважаємо положення, викладені у працях вітчизняних науковців про соціальне виховання й духовний розвиток особистості ( І. Бех, О. Сухомлинська), складників концепції соціалізації особистості (Т. Алексєєнко, І. Звєрєва, А. Капська, I. Рогальська, С. Савченко, С. Харченко); компонентів соціальної компетентності особистості на 
ранніх етапах соціалізації (Ю. Богинська, О. Караман, О. Кононко, С. Курінна, І. Печенко, Р. Пріма, О. Рейпольська) тощо.

Водночас аналіз наукової літератури дає підстави говорити про відсутність стратегії налагодження взаємодії, системного партнерства закладу дошкільної освіти і сім’ї, єдності їхніх вимог та дій, удосконалення виховних впливів в аспекті соціалізації дошкільників, пошуку відповідних оптимальних форм і методів роботи та ін.

Метою статті є висвітлення сутності підготовки майбутніх вихователів до соціалізації дошкільників у взаємодії ЗДО та сім’ї з метою, окреслення змісту, ключових напрямів, форм і методів цієї роботи.

\section{Матеріал і методи досліджень}

Матеріалом для наукової рецепції слугували особисті спостереження та результати критичного опрацювання науково-аналітичних матеріалів українських учених стосовно до аналізу поняття «соціалізація дошкільників», що дало змогу логічно впорядкувати споріднені 3 ним, окреслити їхню ієрархію в аспекті проблеми соціалізації дошкільників у контексті взаємодії ЗДО та сім'ї. У дослідженні було використано методи спостереження, абстрагування, аналізу, синтезу, індукції, дедукції, систематизації, узагальнення, моделювання.

\section{Результати та їхнс обговорення}

Зміст фахової підготовки вихователя ЗДО не може не включати систему сучасних знань про соціалізацію дошкільників, тісно пов'язану зі зростанням числа соціально-педагогічних проблем дітей, мінливим соціальним оточенням, необхідністю реформувати дошкільну освіту тощо.

Як справедливо зауважує I. Рогальська-Яблонська, у майбутніх вихователів необхідно сформувати цілісне уявлення про дитину як суб'єкт і об'єкт соціалізації, знання технології педагогічного супроводу соціалізації 
дошкільника та знань, умінь, навичок 3 методики ознайомлення дітей із суспільним довкіллям (Рогальська, 2008).

Насамперед під соціалізацією розуміємо набуття дітьми соціального досвіду у процесі діяльності, яка передбачає орієнтування в життєвій ситуації, пристосування до навколишніх обставин, опанування їх соціального змісту, цінностей i норм поведінки в суспільстві, вироблення соціокультурного досвіду, власних навичок спілкування та ін. (Діти і соціум, 2006; Кравченко, 2010; Рогальська, 2008).

3 огляду на те, що процес соціалізації дошкільників цілком залежить від їхніх вікових особливостей, зокрема типу провідної діяльності, яким у дітей є:

- до року - спілкування в сім’ї, з батьками, коли через них переймаються родинні цінності, шаблони поведінки, діти відкривають для себе світ;

- від року до трьох - додається спілкування у дитячому колективі (у ЗДО, на ігровому майданчику та ін.), де діти вчаться розуміти одне одного, співчувати, спілкуватися, товаришувати тощо;

- далі до шести років - ваги набуває спілкування, завдяки якому налагоджується діалог із соціумом, присвоюють досвід людства і т.д. (Шахрай, 2010).

Водночас провідна діяльність дошкільників - це гра, саме через неї відбувається їхня соціалізація. За Д. Смелзером, успішна соціалізація особистості зумовлюється дією кількох чинників: очікуванням, зміною поведінки і прагненням відповідати цим очікуванням. До того ж становлення дітей проходить три стадії, серед яких:

- наслідування на копіювання поведінки дорослих;

- ігрова діяльність, що дає їм змогу усвідомити цю поведінку, опанувати «дорослі ролі»;

- групові ігри, у яких діти вчаться задовольняти очікування оточуючих.

Основними умовами успішної соціалізації неповнолітніх науковці називають такі: 
- стан їхнього психічного здоров’я;

- наявність емоційно-комфортної атмосфери в колективі;

- створення сприятливих умов для соціалізації дитини, зокрема для забезпечення психологічного комфорту;

- забезпечення тісної взаємодії педагогів і батьків;

- організація психолого-педагогічного моніторингу динаміки показників здоров’я, виховання і розвитку дітей;

- побудова відносин партнерського співробітництва й готовності працювати в соціально орієнтованому процесі (Литвиненко, 2002:216).

Тобто результатом та показником соціального виховання дітей $\epsilon$ соціальна компетентність, тобто інтегральна характеристика особистості, яка забезпечує іiі інтеграцію в суспільство, продуктивне виконання соціальних ролей, здатність орієнтуватися в мінливому соціальному середовищі й ефективно взаємодіяти з іншими людьми.

Услід за дослідниками (А. Богуш, Л. Варяниця, 3. Возна, Н. Гавриш, С. Курінна, І. Печенко), з огляду на вікові та психологічної особливості дошкільників (3-6 років), складниками їхньої соціальної компетентності вважаємо:

1. Когнітивний компонент:

- первинні уявлення про соціально прийнятні норми життя в сім’ї та дитячому колективі («можна», «не можна», «погано», «добре», «необхідно»);

- поняття про способи взаємодії, спілкування з людьми різного віку і статі;

- розуміння дитиною наслідків своїх та чужих вчинків, їх впливу на емоції інших людей.

2. Емоиійно-почуттєвий компонент:

- ставлення дитини до емоцій, почуттів інших дітей i дорослих;

- терплячість (зачатки толерантності);

- соціальна відповідальність;

- чуйність, співчуття, співучасть;

- повага до іншого; 
- ставлення до себе, упевненість у собі.

3. Мотиваційно-ціннісний компонент:

- сукупність соціальних потреб;

- інтереси;

- ціннісні орієнтації дітей;

- мотивація на успіх у діяльності тощо.

4. Діяльнісно-поведінковий компонент- ие здатність:

- дотримуватися соціально прийнятних норм поведінки;

- вирішувати прості конфліктні й проблемні ситуації;

- вести діалог 3 дорослими та однолітками;

- взаємодіяти у стосунках «дитина - дитина», «дитина дорослий»;

- брати участь у колективних справах, спільних дорученнях;

- контролювати свої дії і т.д.

Організовувати процес соціалізації дошкільників у закладі освіти належить з урахуванням того, що розвиток дітей відбувається динамічно: змінюється тип провідної діяльності, відносини з оточенням і саме це оточення, відбувається самоусвідомлення й самовизначення неповнолітнього.

Однак скеровувати й організовувати процес соціалізації дошкільників вихователі ЗДО мають з огляду на сім'ю, у якій розпочинається соціальне виховання дитини, його активізація чи гальмування. Саме сім'я формує перші уявлення про навколишній світ (адекватні або не дуже), що залежить від життєвих цінностей самих батьків, їхніх понять, зокрема, й про соціалізацію дитини.

У майбутніх вихователів необхідно сформувати знання про різні типи взаємодії членів сім'ї, які впливають на формування в дітей перших стереотипів поведінки i спілкування, серед них:

- співпраця, що передбачає гнучкий розподіл ролей залежно від ситуації, урахування особливостей членів сім’”̈, 
взаємну підтримку і взаємодопомогу, емпатію, готовність вирішувати конфліктні ситуації;

- паритетні відносини, побудовані на рівних правах партнерів, але з нижчим ступенем емпатії та взаємодопомоги, певним прагненням кожного до особистої вигоди;

- змагання, спрямоване на виявлення першості на тлі доброзичливого ставлення до партнера, кооперації, інтересів, емоційної підтримки, емпатії, досягнення реальної переваги;

- конкуренція, тобто пригнічення партнера будь-якими засобами, самоствердження, заздрість, ревнощі до успіхів іншого;

- антагонізм - суперечливість інтересів членів сім’ї, цілей, відносин;

- суперництво - відкрите зіткненнями батьків, неузгодженість сімейних ролей;

- псевдоспівпраця в сім’ї нагадує гіпертрофованість емоційної взаємної підтримки;

- ізоляція передбачає дистантні відносини в сім’ї, емоційну роз'єднаність (Перхайло, 2018: 44-45).

Водночас типовими обставинами, які ускладнюють виховання дитини можуть бути:

а) невиконання батьківських обов'язків щодо виховання дітей, нехтування їхніми інтересами, брутальність тощо;

б) нездатність прищепити дітям працьовитість, безкорисливість, товариськість і т.д.;

в) переважання в сім’ї антигромадських поглядів, шкідливих звичаїв;

г) поганий приклад батьків, аморальний спосіб життя (сварки, пияцтво, наркоманія, проституція) тощо.

Негативно вливають також низька згуртованість та значна розбіжність членів сім'ї у питаннях виховання; незнання батьками психологічних особливостей своєї дитини; гіперпротекція; емоційне відчуження; виховний контроль через культивування почуття провини в дитини; 
авторитарність батьків і т.д. (Литвиненко, 2002; Перхайло, 2018).

Як показує досвід, недоліки у вихованні неповнолітніх у сім'ї зумовлюють викривлення траєкторії їхнього соціального становлення, виникнення у дітей психологічної депривації і девіантної поведінки.

Сказане доводить необхідність спеціальної підготовки батьків та педагогів ЗДО до організації соціалізації дошкільників. Тобто слід не тільки оновити понятійний апарат, систему знань, комплекс фахових компетентностей майбутніх вихователів у професійній підготовці, але й сприяти опануванню ними технологій й механізмів успішної соціалізації дошкільників, оволодіння прийомами іiі оптимізації, налагодження продуктивної взаємодії із сім'ями дітей.

Сказане допоможе перетворити батьків вихованців на однодумців і помічників педагогів. Майбутні вихователі ЗДО повинні оволодіти алгоритмом вибудовування довірливих стосунків з батьками, що передбачає:

не тільки вироблення позитивного образу дитини, але й трансляцію його батькам вихованців завдяки прийому «перестановка акцентів»;

- опору батьків на позитивний образ своєї дитини в сімейному вихованні, спілкуванні, взаємодії;

- виявлення педагогами проблем у сімейному вихованні, корекцію окремих моментів на основі довіри й доброзичливості;

- спільний пошук шляхів подальшої співпраці, зміну стереотипів, шаблонів, відхід від негативних моделей (Левицька, 2011).

Така логіка взаємодії педагогів і сім’ї $€$ ознакою партнерської взаємодії ЗДО та родини, що допомагає вирішувати конфліктні ситуації, попереджувати труднощі й помилки у спілкуванні й вихованні дітей. 
Спираючись на доробки науковців (С. Іванчук, Т. Кравченко, Г. Левицька, С. Литвиненко, О. Суровцева та ін.), виділимо основні, найбільш перспективні напрями співпраці ЗДО і сімей в контексті соціалізації вихованців, серед яких:

1) інформаційно-просвітницька робота педагогів 3 батьками, що забезпечує знаннєву підготовку сім’ї до соціального виховання дітей, стимулювання рефлексії батьків, скеровує процес соціалізації дошкільників (доречні форми i методи: «педагогічна школа» для батьків, психологічні тренінги, індивідуальне консультування, практичні завдання, батьківські збори тощо);

2) цілеспрямований вплив педагогів на соціальне середовище сім’і через вихованців, шляхом усебічного виховання дітей, формування їхніх ціннісних орієнтацій, емоцій і почуттів (емпатія, совість, сором, терпимість, милосердя, щастя, любов до людини i природи); налагодження доброзичливих стосунків між дітьми та їхніми батьками, задоволення потреби дітей у захисті, любові, повазі, розумінні, підтримці, спілкуванні, ставлення до дитини як до цінності, індивідуальності (творчі завдання, повчальні історії, казки, ігрові та тренувальні вправи, спільне дозвілля і спільна праця тощо);

3) активізація партнерства в системі «вихователь батьки - дитина» шляхом розбудови конструктивного діалогу між сім'єю і ЗДО для належної соціалізації дитини, що вимагає впровадження особистісно орієнтованого, індивідуального підходу, співпраці, партнерства, взаємної відповідальності сім’ї і закладу освіти, довіри за допомогою використання інтерактивних методів роботи з батьками й дітьми (рольова гра, робота в малих групах, психогімнастичні вправи, презентація власного досвіду сімейного виховання й аргументація його доцільності, участь у виховних заходах і т.д.) (Кравченко, 2010; Левицька, 2011; Литвиненко, 2002). 
Професійна підготовка майбутніх вихователів ЗДО до налагодження належної взаємодії із сім'ями 3 метою активізації соціалізації дітей потребує формування у студентів здатності практично реалізувати низку принципів партнерства, а саме:

- гуманістичного: визначення й реалізація інтересів, потреб батьків і дітей у процесі організації спільної роботи та спілкування, прийняття їх як рівнозначних партнерів; максимальне врахування позитивних рис батьків і дітей; оптимістичне ставлення до них, повага один до одного;

- співробітництва та партнерства: визнання батьків суб’єктами співпраці 3 педагогами, знання психології дорослих, їхньої компетентності, життєвого й соціального досвіду, заохочення до активності, ініціативності, відповідальності за свої дії; подолання міжособистісної напруги, конфліктності; спільне вирішення проблем, пов'язаних із соціалізацією дитини на взаємоузгоджених засадах;

- нарощування виховних впливів: зближення, визнання й прийняття намірів, очікувань, цілей батьків та вихователів ЗДО в організації соціалізації дітей (обговорення мети, обмін інформацією, спільна робота) тощо (Кравченко, 2010).

Злагоджена взаємодія сім’ї і вихователів у процесі педагогічного супроводу допомагає повною мірою реалізувати можливості соціалізації дитини, оптимізувавши:

1) адаптацію дошкільника до умов життєдіяльності, включення у світ людських стосунків, формування відкритості до соціуму;

2) динаміку й розвиток самоусвідомлення, зміну уявлення про себе і ставлення до себе у процесі життєдіяльності, формування готовності до сприймання соціальної інформації, соціальної поведінки;

3) вироблення в дитини суб'єктивної життєвої позиції та ін. (Рогальська, 2008). 
Обов’язково в умовах закладу вищої освіти студентів необхідно підготувати до реалізації соціального партнерства у сфері освіти як специфічного типу суспільних відносин у процесі взаємодії закладу освіти і соціуму, спрямованого на досягнення спільної мети, взаємовигоди, взаємодопомоги, взаємовідповідальності. Саме в такому контексті налагодження взаємодії сім’ї й ЗДО з метою організації соціалізації дошкільників є найбільш продуктивним.

Інноваційна спрямованість фахової підготовки майбутніх вихователів до названого напряму роботи має за мету модернізацію педагогічного супроводу соціалізації дошкільників. Не менш важливою є здатність випускників здійснювати психолого-педагогічне забезпечення освітнього процесу, доцільно організовувати взаємодію в ході ігорзанять, змістовного життя дітей і керівництво дитячою діяльністю (спілкування, предметна, ігрова тощо), корекційні впливи, створювати предметне розвивальне середовище як умову соціального розвитку дитини та ін.

Професійне навчання майбутніх вихователів обов'язково має включати в себе підготовку до здійснення системної соціально-педагогічної роботи, що сприяє позитивній соціалізації дітей, захисту їхніх прав та інтересів, ознайомленню 3 навколишнім світом людей, організації спілкування; наданню консультативної допомоги батькам, формуванню у них знань із ключовими поняттями дошкільної педагогіки і психології, прийомами виховання й навчання дошкільників.

Важливим складником освітнього процесу в цьому світлі $є$ практичний компонент. Під час практики у студентів: формуються поняття про майбутні професійні ролі, інтерес до такої роботи, готовність реалізувати завдання соціалізації дітей, поглиблюються теоретичні знання і вдосконалюються вміння, зокрема використовувати різноманітні форми, методи й засоби відповідно до поставлених конкретних завдань; виробляється мотивація до самовдосконалення тощо. 
Фахова підготовка майбутніх вихователів ЗДО до взаємодії із сім'ями неодмінно пов'язана із виробленням у студентів комплексу професійно важливих якостей, а саме: психологічних характеристик (психічні та інтелектуальні якості, професійна самосвідомість); морально-етичних і вольових якостей (емпатійність, тактовність, уважність, толерантність, гуманність, чесність, моральність, етична поведінка, відповідальність та ін.); професійно-операційних якостей і здібностей (професійні знання, компетентності).

Окремо слід сказати про необхідність вироблення у студентів навичок асертивної поведінки, що грунтується на повазі до себе та інших, гідності, здатності протидіяти маніпуляціям, дружелюбності, готовності до співробітництва тощо.

На наш погляд, оновленню фахової підготовки майбутніх вихователів ЗДО, зокрема і в контексті висвітленої теми, сприяє застосування активних методів та нестандартних форм навчання студентів, серед яких:

- моделювання типових ситуацій професійної діяльності вихователя, пов'язаних із організацією взаємодії з батьками, вирішення проблем соціального виховання дітей;

- евристичний метод, що активізує аналітичну діяльність педагога, готовність міркувати, аргументувати, обстоювати свою позицію у спілкуванні з батьками;

- групова робота студентів та робота в парах, спрямована на вироблення навичок працювати в команді, співпрацювати, оптимізувати групову діяльність;

- рольові й ділові ігри, які дають змогу опанувати професійні ролі та функції в умовах вищої школи;

- метод комунікативних і професійних тренінгів, що вдосконалює комунікативну компетентність;

- технологія рефлексивного навчання, яка розвиває основні рефлексивні вміння, стимулює особистісне та професійне становлення студентів тощо (Матішак, 2015; Сайко, 2004). 
До того ж якість професійної освіти майбутніх вихователів ЗДО значною мірою залежить від низки навчальних дисциплін. На думку Н. Сайко, такій підготовці сприяють введення до програми з дошкільної педагогіки розділу «Соціалізація дошкільника», спецсемінару «Теоретико-методичні основи соціалізації дітей дошкільного віку», розкриття таких тем, як «Соціалізація дошкільника», «Загальні питання процесу соціалізації дошкільника», «Основи формування елементів світогляду дітей дошкільного віку», Н. Суховєєва пропонує дисципліну «Соціальна педагогіка в дошкільному навчальному закладі» та ін., що допоможуть сформувати у студентів знання про суспільну вагу проблеми соціалізації дошкільників, оволодінню технологією організації соціалізації дітей, а також стимулюванню процесу професійного самовдосконалення для засвоєння форм і методів соціалізації та їх практичної реалізації.

\section{Висновки}

Отже, вивчення проблеми підготовки майбутніх вихователів до взаємодії із сім'єю в контексті соціалізації дошкільників дає змогу визначити кілька ключових положень.

Соціалізацію слід розглядати як поступове входження дитини у систему соціальних зв'язків, опанування соціокультурного досвіду через їі суб'єктивне пізнання суспільного довкілля та конструювання образу соціального світу. Розвиток особистості - це завжди переплетення процесів індивідуалізації та соціалізації, коли, засвоївши соціальний досвід, правила, норми, еталони і способи поведінки в соціумі, індивід прагне до автономності в ньому, захисту своєї неповторності, незалежності, творчої співпраці 3 іншими людьми (Рогальська, 2008).

Системно організовувати, скеровувати й оптимізовувати процес соціалізації дошкільників можливо 
тільки у взаємодії, партнерстві сім’ї та закладу дошкільної освіти. Завдяки співпраці двох найголовніших інститутів соціалізації - сім’і і закладу освіти - має забезпечуватися вирішення суперечностей між батьками, дітьми й педагогами, організація різних видів спільної роботи, узгодження інтересів усіх учасників взаємодії. У такий спосіб формується найбільш доцільний соціальний контекст розвитку особистості дошкільника.

Метою професійної педагогічної освіти сьогодні $\epsilon$ підготовка компетентного фахівця інноваційного типу, здатного реалізувати освітні стандарти, застосовувати нові освітні технології, чому сприяє оновлення змісту професійного навчання майбутніх вихователів, використання доцільних засобів, методів і форм його реалізації.

Удосконалити процес підготовки вихователя ЗДО до налагодження взаємодії із сім'єю дає змогу реалізація низки педагогічних умов, серед яких:

- системний підхід до формування професійної та соціальної компетентності майбутніх педагогів;

- оволодіння студентами різними технологіями налагодження взаємодії сім'ї і закладу освіти;

- розвиток у майбутніх вихователів мотивації до професійного самовдосконалення;

- оптимальний добір методів, прийомів i засобів організації соціалізації дошкільників, використання в освітньому процесі активних методів виховання;

- застосування інтерактивних технологій як основи професійної підготовки студентів, використання внутрішньопредметних та міждисциплінарних зв'язків у вищій школі.

Запропонована стаття не висвітлює всіх аспектів означеної проблеми. Перспективи подальших досліджень убачаємо в необхідності обгрунтування інноваційних шляхів, змісту і форм партнерства закладів освіти та сім’ї щодо організації соціалізації дітей різного віку, особливостей 
використання сучасних інноваційних технологій роботи 3 батьками.

\section{Література}

1. Діти i соціум: особливості соціалізації дітей дошкільного та молодшого шкільного віку / за заг. А. М. Богуш, Н. В. Гавриш. Луганськ : Альма-матер, 2006. 368 c.

2. Кравченко Т. Теоретико-методичні засади соціалізації дітей шкільного віку : автореф. дис. ... д-ра пед. наук : 13.00.07. К. 2010. 41 с.

3. Левицька Г. М. Адаптація дітей раннього віку до дитячого садка. Бібліотечка вихователя дитячого садка. 2011. №3. C.76-91.

4. Литвиненко С. Я. Дитина i середовище: проблеми взаємодії. Оновлення змісту та методів навчання $і$ виховання в закладах освіти : зб. наук. праць. Рівне : РДГУ, 2002. (№ 22). C. 216-219.

5. Матішак М.В Напрями співпраці педагога $з$ батьками у процесі формування соціальної компетентності молодших школярів. Молодий вчений. 2015. лютий № 2 (17). С. 279-282.

6. Національна стратегія розвитку освіти в Україні на 2012-2021 pp. URL: http://oneu.edu.ua/wp-content/ uploads/2017/11/nsro_1221.pdf

7. Перхайло Н.А. Партнерство суб'єктів соціальної роботи : навч. посіб. для студентів спеціальності 231 Соціальна робота. Переяслав-Хмельницький : «Калина», 2018. 206 c.

8. Рогальська I. П. Соціалізація особистості у дошкільному дитинстві: сутність, специфіка, супровід : монографія. Київ : Міленіум, 2008. 400 с.

9. Сайко Н. О. Професійно-педагогічна підготовка майбутніх вихователів до соціалізації дітей дошкільного віку : дис. ... канд. пед. наук : 13.00.04. Київ, 2004. 262 с.

10. Шахрай В. Критерії та показники визначення сформованості соціальної компетентності особистості. URL: http://narodnaosvita.kiev.ua/Narodna_osvita/vupysku/15/statti/sh ahray.htm (дата звернення: 14.09.2020). 
Рожко-Павлишин Т.A.

\section{Підготовка майбутніх вихователів до соціалізації дошкільників у взасмодії ЗДО і сім’ї}

\section{Анотація}

Запропонована стаття висвітлює актуальні питання підготовки майбутніх вихователів закладів дошкільної освіти до соціалізації дітей дошкільного віку в контексті взаємодії ЗДО та сім’ї. Автор розкриває сутність понять «соціалізація дошкільника», «соціальна компетентність дошкільника» та «взаємодія ЗДО і сім’ї. Розкриває суспільне значення названої проблеми, систему організації соціалізації дошкільників, іiі особливостей у дітей цього віку, напрямів, форм і методів названої роботи.

Показана роль сім’ї та ЗДО як найважливіших соціальних інститутів, що визначають специфіку соціального виховання, становлення неповнолітнього, проблеми i можливості соціалізації дітей в родині й закладі освіти.

У статті запропоновані педагогічні умови оптимізації професійної підготовки студентів до організації соціалізації дошкільників.

Ключові слова: заклад дошкільної освіти, соціалізація дошкільника, взаємодія ЗДО і сім'ї, вихователь закладу дошкільної освіти, підготовка майбутніх вихователів ЗДО до налагодження взаємодії ЗДО і сім’і.

\section{Рожко-Павлишин Т.А.}

Подготовка будущих воспитателей к социализации дошкольников во взаимодействии УДО и семьи

\section{Аннотация}

Предлагаемая статья освещает актуальные вопросы подготовки будущих воспитателей учреждений дошкольного 
образования в социализации детей дошкольного возраста в контексте взаимодействия УДО и семьи. Автор раскрывает сущность понятий «социализация дошкольника», «социальная компетентность дошкольника» и «взаимодействие УДО и семьи». Раскрывает общественное значение названной проблемы, систему организации социализации дошкольников, ее особенностей у детей этого возраста, направлений, форм и методов названной работы.

Показана роль семьи и УДО как важнейших социальных институтов, определяющих специфику социального воспитания, становления несовершеннолетнего, проблемы и возможности социализации детей в семье и учебном заведении.

В статье предложены педагогические условия оптимизации профессиональной подготовки студентов к организации социализации дошкольников.

Ключевые слова: учреждение дошкольного образования, социализация дошкольника, взаимодействие УДО и семьи, воспитатель учреждения дошкольного образования, подготовка будущих воспитателей УДО к налаживанию взаимодействия УДО и семьи. 